\title{
PENGARUH KOMBINASI NUTRISI ANORGANIK DAN PUPUK HAYATI TERHADAP POPULASI Azotobacter sp, KANDUNGAN KLOROFIL, SERAPAN N, DAN HASIL TANAMAN TOMAT PADA SISTEM HIDROPONIK
}

\section{The Effect of Inorganic Nutrients and Biofertilizer on The Population of Azotobacter sp., Chlorophyll Content, Nitrogen Uptakes, and Yield of Tomatoes Plants in Hydroponic}

\author{
Nandha Afrilandha* dan Mieke Rochimi Setiawati \\ Fakultas Pertanian, Universitas Padjadjaran, Jalan Raya Bandung-Sumedang km 21 \\ Jatinangor, Sumedang 45363
}

*Alamat Korespondensi: nandhakaka@gmail.com

\begin{abstract}
ABSTRAK
Budidaya hidroponik belum efisien untuk digunakan, salah satu penyebabnya adalah tingginya kebutuhan nutrisi. Pemanfaatan pupuk hayati diharapkan bias mengefisiensikan penggunaan nutrisi dan meningkatkan produktivitas tanaman tomat Tujuan penelitian ini untuk mengetahui pengaruh kombinasi nutrisi anorganik dan pupuk hayati terhadap populasi Azotobacter sp, serapan N, kandungan klorofil, dan hasil tanaman tomat pada sistem hidroponik. Penelitian ini dilakukan pada bulan Agustus - November 2017 di Rumah Kaca Kebun Percobaan Ciparanje Universitas Padjadjaran, Jatinangor, Kabupaten Sumedang, Jawa Barat. Metode penelitian ini menggunakan rancangan acak kelompok (RAK). Kombinasi perlakuan terdiri atas rekomendasi nutrisi anorganik dengan konsentrasi 100\%, 75\%, dan 50\% dan rekomendasi pupuk hayati 100\%, 75\%, 50\%, dan 25\%. Variabel yang diamati meliputi populasi Azotobacter sp, kandungan klorofil, serapan N, jumlah buah tomat dan bobot buah tomat. Hasil penelitian ini menunjukkan bahwa tidak terdapat pengaruh nyata pemberian nutrisi anorganik dan pupuk hayati terhadap populasi Azotobacter sp, kandungan klorofil, serapan N, serta hasil tanaman tomat. Pemberian perlakuan 50\% nutrisi Anorganik $+100 \%$ pupuk hayati dapat meningkatkan bobot buah sebesar $40 \%$ dibandingkan pemberian $100 \%$ nutrisi anorganik.
\end{abstract}

Kata kunci: Azotobacter sp., klorofil, nutrisi anorganik, hydroponik, tomat

\begin{abstract}
Hydroponic cultivation is not efficient because of its high demand for nutrients. Therefore, the utilization of inorganic nutrients and biofertilizer is expected to improve the efficiency of nutrients uptake and increase the productivity. The aim of research was to determine the effect of combination of inorganic nutrient dosage and biofertilizer on the population of Azotobacter sp, $N$ uptakes, chlorophyll content, and yield of tomatoes plantin hydroponic systems. This experiment was conducted on August - November 2017 at GreenhouseExperiment Garden Ciparanje Padjadjaran University, Jatinangor, Sumedang Regency, West Java. This research method used Randomized Block Design (RBD). The treatment combination consisted of dosage recommendation of inorganic nutrition with 100\%, 75\% and 50\% concentrations, and 100\%, 75\%, 50\%, and 25\% of biofertilizer. The variables observed included the population of Azotobacter sp, chlorophyll content, $N$ uptake, number of tomatoes and weight of tomatoes. The result of this study indicated that the effect of application both, inorganic nutrients and biofertilizer did not significantly affect the population of Azotobacter sp, chlorophyll content, $N$ uptakes, and yield of tomatoes. The application of 50\% Inorganic nutrition $+100 \%$ of biofertilizer increased fruit weight by $40 \%$ compared to $100 \%$ of inorganic nutrients.
\end{abstract}

Keywords: Azotobacter sp., chlorophyll, biofertilizer, hydroponic, tomato

\section{PENDAHULUAN}

Tomat (Lycopersicon esculentum

Mill) merupakan sayuran buah yang tergolong tanaman semusim dan termasuk ke dalam famili Solanaceae. Buah tomat memiliki senyawa diantaranya solanin, saponin, asam folat, asam malat, asam sitrat, bioflavonoid (termasuk lycopene, $\alpha$ dan ß-carotene), protein, lemak, vitamin, mineral dan histamin (Novelina et al., 2016) 
Tomat juga mengandung beberapa unsur seperti kalium, fosfor, magnesium, dan kalsium (United States Department of Agriculture, 2009), di samping itu juga mengandung antioksidan yang dapat mengurangi penyakit kanker (Miller et al., 2002).

Berdasarkan informasi Badan Pusat

Statistik dan Direktorat Jenderal Hortikultura (2014) produksi tomat di Indonesia mengalami fluktuasi dan cenderung menurun dari tahun 2011 sampai 2014. Data produktivitas tomat tahun 2013 sebesar 16,61ton $\mathrm{ha}^{-1}$ dan tahun 2014 produktivitas tomat mengalami penurunan menjadi 15,52 ton $\mathrm{ha}^{-1}$. Angka produksi tomat dari tahun 2011 sampai 2014 pun cenderung mengalami penurunan, yakni produksi tomat tertinggi dicapai pada tahun 2013 sebesar 992.780 ton, sedangkan tahun 2014 produksi tomat hanya 915.987 ton.

Produktivitas tomat di Indonesia masih tergolong rendah. Pada tahun 2010 produktivitas tomat di Indonesia baru mencapai 14,58 ton $\mathrm{ha}^{-1}$. Jumlah ini berbeda jauh dengan produktivitas tomat di negara lainnya, misalkan Amerika Serikat yang telah memproduksi tomat sebanyak 69,40 ton ha ${ }^{-1}$ di tahun 2002 (Marliah dkk., 2012).

Rendahnya produksi buah tomat dapat disebabkan oleh berbagai faktor seperti varietas yang ditanam tidak cocok, kultur teknis yang kurang baik, atau pengendalian organisme pengganggu tanaman yang tidak efektif. Faktor lain yang menyebabkan penurunan produksi buah tomat antara lain penggunaan pupuk yang kurang efisien serta pola tanam yang kurang tepat. Perbaikkan sistem budidaya tomat terus dilakukan untuk meningkatkan kualitas dan kuantitas hasil tanaman tomat (Wijayanti dan Susila, 2013). Salah satu metode yang dapat diterapkan untuk meningkatkan hasil tanaman tomat yaitu dengan hidroponik.

Hidroponik merupakan sistem budidaya tanpa menggunakan tanah, tetapi menggunakan media arang sekam, rockwool, batu apung, pasir, kerikil, dan dapat dengan media air dan udara. Keuntungan hidroponik diantaranya tidak menggunakan media tanah, biaya pemakaian air lebih hemat karena dapat digunakan kembali, dapat mengontrol tingkat gizi secara keseluruhan, tidak ada pencemaran nutrisi yang dilepaskan ke lingkungan karena sistem terkontrol, memperoleh hasil yang stabil dan tinggi, haama dan penyakit lebih mudah disingkirkan daripada di tanah karena wadahnya mobilitas (Maboko, 2014).

Salah satu komponen penting dalam sistem hidroponik adalah larutan nutrisi. Umumnya, larutan nutrisi yang diberikan terdiri dari hara makro (N,P, K, Ca, danMg) pada larutan stok A dan hara mikro (Fe, B, $\mathrm{Mn}, \mathrm{Cu}, \mathrm{Na}, \mathrm{Mo}$, dan $\mathrm{Zn}$ ) pada larutan stok B (Bailey, 2017). Larutan nutrisi tersebut 
p-ISSN: 1410-0029; e-ISSN2549-6786

Agrin Vol. 22, No. 1, April 2018

diperlukan untuk memperbaiki

pemberian larutan nutrisi pada sistem pertumbuhan tanaman (Karsono dkk., 2002). Aplikasi dosis larutan nutrisi yang rendah pada sistem hidroponik tidak akan menimbulkan dampak yang nyata, sedangkan dengan dosis tinggi akan menyebabkan keracunan bagi tanaman sehingga dapat mempengaruhi pertumbuhan dan perkembangan tanaman yang berakibat pada bobot buah tanaman (Novizan, 2003).

Aplikasi pupuk hayati mampu mensubtitusi kekurangan nutrisi yang dibutuhkan tanaman serta dapat mengurangi efek keracunan bagi tanaman akibat dosis tinggi, khususnya tanaman tomat. Pupuk hayati merupakan preparasi yang mengandung sel organisme (bakteri, jamur, dan alga) mikroba penambat $\mathrm{N}$, pelarut dan mobilisasi $\mathrm{P}$, atau selulotik yang bertujuanmeningkatkan kandungan karbon organik, meningkatkan nutrisi hara bagi tanaman, sebagai agen antagonis terhadap patogen, dan sebagainya (Mohapatra et al., 2013).

Bion-Up merupakan konsorsium pupuk hayati berbahan aktif lebih dari satu mikroba tanah, yakni mikroba penambat $\mathrm{N}$ Azotobactersp, Azospirillum sp, dan bakteri endofitik, serta bakteri pelarut fosfat dan jamur pelarut fosfat (Setiawati, 2016). Aplikasi konsorsium hayati diharapkan mampu memberikan solusi bagi petani sayuran dalam hal mengefisiensikan 
yaitu arang sekam, cocopeat, air, polybag, benih tomat varietas Martha, nutrisi anorganik, pupuk hayatiBion-Up produksi Lab Biologi Tanah Unpad yang terdiri dari campuran isolat Azotobacter sp, Azospirilium sp, bakteri endofitik, dan mikroba (bakteri dan jamur) pelarut fosfat.

Metode penelitian menggunakan metode Rancangan Acak Kelompok (RAK), yang diulang sebanyak 4 kali. Kombinasi perlakuan terdiri dari perlakuan $\mathrm{A}=100 \%$ nutrisi anorganik (kontrol), perlakuan $\mathrm{B}=50 \%$ nutrisi anorganik + $100 \%$ pupuk hayati, perlakuan $\mathrm{C}=75 \%$ nutrisi anorganik $+100 \%$ pupuk hayati, perlakuan $\mathrm{D}=100 \%$ nutrisi anorganik + $25 \%$ pupuk hayati, perlakuan $\mathrm{E}=100 \%$ nutrisi anorganik $+25 \%$ pupuk hayati, perlakuan $\mathrm{F}=100 \%$ nutrisi anorganik + $25 \%$ pupuk hayati, perlakuan $\mathrm{G}=100 \%$ nutrisi anorganik $+25 \%$ pupuk hayati sehingga terdapat 28 unit percobaan.

Tanaman disemai menggunakan baki selama satu bulan kemudian pada umur 40 hari setelah semai (HSS) tanaman dipindahkan ke polybag. Pupuk hayati diberikan sebanyak satu kali saat pindah tanam, sedangkan nutrisi anorganik diberikan 3 kali sehari sebanyak $50 \mathrm{~mL}$ per polybag (150 mL per polybag per hari). Setelah satu minggu dosis ditingkatkan menjadi $100 \mathrm{~mL}$ per polybag (300 mL per polybag per hari). Setiap satu minggu dosis ditambah $50 \mathrm{~mL}$ per polybag. Mekanisme pemberian larutan nutrisi menggunakan penyiraman secara manual.

Pengamatan yang dilakukan dalam penelitian ini meliputi populasi Azotobacter sp, kandungan klorofil, serapan $\mathrm{N}$, serta hasil tanaman tomat berupa jumlah buah dan bobot buah.

\section{HASIL DAN PEMBAHASAN}

\section{Populasi Azotobacter sp}

Bakteri Azotobacter sp. memiliki peran dalam proses pertumbuhan tanaman yaitu sebagai penambat nitrogen sekaligus penghasil fitohormon yang mendukung proses pertumbuhan tanaman. Populasinya yang tinggi diharapkan dapat membantu proses pemenuhan jumlah pasokan nitrogen dengan mengsekresikan hormone tumbuh saat fase vegetatif sehingga menghasilkan fotosintat untuk keperluan fase generatif tanaman. Keberadaan Azotobacter sp. ini dapat memberikan respon positif dengan kombinasi nutrisi anorganik dalam sistem hidroponik.

Tabel 1. menunjukkan bahwa pemberian nutrisi anorganik yang dikombinasikan dengan pupuk hayati tidak berpengaruh nyata terhadap populasi Azotobacter sp. Hal tersebut diduga terjadi kompetisi nutrisi antara mikroba indigenous dengan bakteri Azotobacter melalui eksudat akar tanaman. Senyawasenyawa eksudat akar yang dikeluarkan oleh tanaman melalui mekanisme difusi, 
saluran ion, dan transport vesikula dari membrane sel hingga ke lingkungan (Walker et al., 2003). Pengeluaran eksudat akar tersebut diduga bersumber juga dari nutrisi anorganik yang diberikan selama penelitian ini karena nutrisi tersebut sudah dalam bentuk tersedia ketika bereaksi dengan air (Cardoso et al., 2016).

Faktor lain yang menyebabkan pertumbuhan mikroba diantaranya adalah suhu dan kelembaban. Menurut Okere and Semple (2012) suhu dan kelembaban merupakan faktor utama yang mempengaruhi aktivitas mikroorganisme pada iklim yang berbeda. Hal ini didukung oleh pernyataan Shelton and Parkin, (1991) kelembaban secara langsung dapat mengendalikan aktivitas mikroorganisme karena kelembaban yang buruk dapat mengganggu aktivitas microorganisme. Pada penelitian ini suhu lingkungan mencapai rata-rata sebesar $31,8^{\circ} \mathrm{C}$, sedangkan menurut Hindersah dan Sudirja (2010) pertumbuhan optimum Azotobacter mencapai suhu optimum sekitar $30^{\circ} \mathrm{C}$ dan apabila suhu berada dibawah $28^{\circ} \mathrm{C}$ atau diatas $32^{\circ} \mathrm{C}$ dapat menurunkan pertumbuhan Azotobacter sp (Dhanasekar et al., 2003).

Tabel 1. Pengaruh pemberian nutrisi anorganik dan pupuk hayati terhadap populasi Azotobacter sp.

\begin{tabular}{lc}
\hline Perlakuan & Populasi Azotobacter sp. $\left(\mathrm{CFU} \mathrm{g}^{-1}\right)$ \\
\hline A (100\% Nutrisi Anorganik + Tanpa Pupuk Hayati) & $2,89 \times 10^{6}$ \\
B (50\% Nutrisi Anorganik + 100\% Pupuk Hayati) & $2,99 \times 10^{6}$ \\
C (75\% Nutrisi Anorganik + 100\% Pupuk Hayati) & $3,58 \times 10^{6}$ \\
D (100\% Nutrisi Anorganik + 25\% Pupuk Hayati) & $3,82 \times 10^{6}$ \\
E (100\% Nutrisi Anorganik + 50\% Pupuk Hayati) & $2,63 \times 10^{6}$ \\
F (100\% Nutrisi Anorganik + 75\% Pupuk Hayati) & $2,41 \times 10^{6}$ \\
G (100\% Nutrisi Anorganik + 100\% Pupuk Hayati) & $3,22 \times 10^{6}$ \\
\hline
\end{tabular}

Keterangan: Perlakuan tidak berpengaruh nyata terhadap respon berdasarkan analisis ragam taraf nyata 5\% sehingga tidak dilakukan uji lanjut Duncan pada taraf nyata 5\%.

Tabel 2. Pengaruh pemberian nutrisi anorganik dan pupuk hayati terhadap kandungan klorofil

\begin{tabular}{lr}
\hline \multicolumn{1}{c}{ Perlakuan } & Kandungan Klorofic \\
\hline A (100\% Nutrisi Anorganik + Tanpa Pupuk Hayati) & 42,87 \\
B (50\% Nutrisi Anorganik + 100\% Pupuk Hayati) & 43,94 \\
C (75\% Nutrisi Anorganik + 100\% Pupuk Hayati) & 42,61 \\
D (100\% Nutrisi Anorganik + 25\% Pupuk Hayati) & 46,22 \\
E (100\% Nutrisi Anorganik + 50\% Pupuk Hayati) & 54,39 \\
F (100\% Nutrisi Anorganik + 75\% Pupuk Hayati) & 46,32 \\
G (100\% Nutrisi Anorganik + 100\% Pupuk Hayati) & 43,89
\end{tabular}

Keterangan: Perlakuan tidak berpengaruh nyata terhadap respon berdasarkan analisis ragam taraf nyata 5\% sehingga tidak dilakukan uji lanjutDuncan pada taraf nyata 5\%. 


\section{Kandungan Klorofil}

Pengamatan jumlah klorofil dalam daun dilakukan pada saat tanaman tomat mencapai fase vegetatif maksimum. Fase pertumbuhan vegetatif maksimum tanaman tomat terjadi pada saat tanaman berumur 5 MST (Salik et al., 2000).

Berdasarkan Tabel 2. menunjukkan pemberian nutrisi anorganik dan pupuk hayati tidak berpengaruh nyata terhadap kandungan klorofil pada daun. Tinggi atau rendahnya kandungan klorofil berbanding lurus terhadap ketersediaan unsur nitrogen dan berperan penting dalam proses fotosintesis (Sampson et al., 2003). Semakin tinggi jumlah pasokan nitrogen yang tersedia oleh tanaman maka kandungan klorofil pada daun semakin tinggi sehingga proses fotosintesis berlangsung dengan cepat. Pernyataan tersebut didukung oleh penelitian Larimi et al. (2014) yang menjelaskan bahwa pemberian pupuk anorganik memiliki respon positif terhadap peningkatan kandungan nitrogen dan luas daun yang diantaranya berkorelasi positif terhadap peningkatan kandungan klorofil a dan $b$ yang mengindikasikan total jumlah klorofil pada daun tanaman.

Pada perlakuan E (100\% Nutrisi Anorganik + 50\% Pupuk Hayati) Tabel 2. Memperlihatkan terdapat sebuah peranan pupuk hayati dalam menambah jumlah klorofil pada daun sehingga memperoleh kandungan klorofil lebih besar pada akhir pengamatan. Hal tersebut didukung oleh penelitian Rueda et al., (2016) yang menjelaskan bahwa pemberian pupuk hayati yang mengandung PGPR Azotobacter sp. yang dikombinasikan dengan unsur nitrogen 100 ppm dapat meningkatkan jumlah kandungan klorofil daun sebesar 53,37 CCI dibandingkan dengan kontrol pada hidroponik tanaman strawberi. Hal tersebut diduga Azotobacter sp. melakukan aktivitas penambatan $\mathrm{N}$ secara bebas di udara dan mendapatkan sumber nutrisi dari $\mathrm{N}_{2}$.

Namun, pada penelitian ini peran pupuk hayati dalam meningkatkan kandungan klorofil pada daun masih belum efektif dan efisien jika dibandingkan dengan perlakuan A $(100 \%$ Nutrisi Anorganik + Tanpa Pupuk Hayati). Hal ini disebabkan oleh nutrisi anorganik yang diberikan pada tanaman sudah dalam bentuk tersedia (Cardoso, 2016) pada saat bereaksi dengan air sehingga ketersediaan hara dimungkinkan jauh lebih banyak dari peranan penambatan $\mathrm{N}$ secara bebas oleh mikroba.

\section{Serapan N}

Analisis serapan $\mathrm{N}$ dilakukan pada sampel daun, yaitu pada tajuk pada saat vegetatif maksimum. Nilai serapan $\mathrm{N}$ berbanding lurus dengan persentase kandungan nitrogen. Berikut pengaruh 
pemberian nutrisi anorganik dan pupuk hayati terhadap serapan $\mathrm{N}$ pada Tabel 3.

Berdasarkan Tabel 3. menunjukkan bahwa tidak terdapat pengaruh nyata antara pemberian nutrisi anorganik dengan pupuk hayati terhadap serapan N. Hal ini diduga karena bakteri yang terkandung dalam pupuk hayati tidak bekerja akibat sudah tersedianya unsur hara $\mathrm{N}$ pada media tanam. Nutrisi anorganik yang diberikan berupa bentuk garam-garam mineral hidroponik diduga ketika bereaksi dengan air menghasilkan ion-ion garam yang artinya sudah tersedia oleh tanaman (Cardoso, 2016). Kondisi tersebut memungkinkan bahwa jumlah ketersediaan hara pada nutrisi lebih banyak dibandingkan dengan aktivitas mikroba dalam mensuplai hara pada media. Hal tersebut didukung oleh pernyataan Hardjowigeno (2010) yang menjelaskan bahwa penyerapan unsur hara oleh tanaman dipengaruhi oleh ketersediaan unsur hara pada media tanam, sehingga kadar $\mathrm{N}$ yang rendah berbanding lurus dengan rendahnya serapan $\mathrm{N}$ tanaman, melainkan kadar $\mathrm{N}$ yang tinggi akan berbanding lurus dengan nilai serapan $\mathrm{N}$ yang tinggi juga.

\section{Hasil Tanaman Tomat}

Kriteria tomat yang siap panen dilihat dari warna buah yaitu $25 \%$ sudah berwarna kuning dan bentuk buah sudah tidak terlalu

Tabel 3. Pengaruh pemberian nutrisi anorganik dan pupuk hayati terhadap serapan $\mathrm{N}$

\begin{tabular}{lc}
\hline Perlakuan & Serapan N (mg/tanaman) \\
\hline A (100\% Nutrisi Anorganik + Tanpa Pupuk Hayati) & 59,60 \\
B (50\% Nutrisi Anorganik + 100\% Pupuk Hayati) & 57,74 \\
C (75\% Nutrisi Anorganik + 100\% Pupuk Hayati) & 47,16 \\
D (100\% Nutrisi Anorganik + 25\% Pupuk Hayati) & 59,14 \\
E (100\% Nutrisi Anorganik + 50\% Pupuk Hayati) & 56,56 \\
F (100\% Nutrisi Anorganik + 75\% Pupuk Hayati) & 65,80 \\
G (100\% Nutrisi Anorganik + 100\% Pupuk Hayati) & 53,81 \\
\hline
\end{tabular}

Keterangan: Perlakuan tidak berpengaruh nyata terhadap respon berdasarkan analisis ragam taraf nyata 5\% sehingga tidak dilakukan uji lanjut pada taraf nyata 5\%.

Tabel 4. Pengaruh pemberian nutrisi anorganik dan pupuk hayati terhadap jumlah dan bobot buah

\begin{tabular}{lcc}
\hline \multicolumn{1}{c}{ Perlakuan } & Jumlah buah & Bobot buah (g) \\
\hline A (100\% Nutrisi Anorganik + Tanpa Pupuk Hayati) & 25 & 1194 \\
B (50\% Nutrisi Anorganik + 100\% Pupuk Hayati) & 25 & 1668 \\
C (75\% Nutrisi Anorganik + 100\% Pupuk Hayati) & 22 & 1297 \\
D (100\% Nutrisi Anorganik + 25\% Pupuk Hayati) & 24 & 1482 \\
E (100\% Nutrisi Anorganik + 50\% Pupuk Hayati) & 24 & 1443 \\
F (100\% Nutrisi Anorganik + 75\% Pupuk Hayati) & 24 & 1386 \\
G (100\% Nutrisi Anorganik + 100\% Pupuk Hayati) & 29 & 1628 \\
\hline
\end{tabular}

Keterangan: Perlakuan tidak berpengaruh nyata terhadap respon berdasarkan analisis ragam taraf nyata 5\% sehingga tidak dilakukan uji lanjut Duncan pada taraf nyata 5\%. 
keras. Pemanenan buah tomat dilakukan pada saat tanaman tomat berumur 85 HSS. Pada pemanenan buah tomat dilakukan sampai tandan ke lima dengan mengukur jumlah buah dan bobot buah untuk mengetahui efektivitas terhadap pemberian perlakuan yang diberikan.

Berdasarkan Tabel 4. menunjukkan pemberian nutrisi anorganik dan pupuk hayati tidak terdapat pengaruh nyata terhadap jumlah buah dan bobot buah tanaman tomat. Hal ini menandakan bahwa konsentrasi pupuk hayati yang diberikan tidak berpengaruh nyata terhadap jumlah buah dan bobot buah. Namun, apabila dilihat dari segi efisiensi pemupukan, perlakuan B memberi kenaikan bobot buah sebesar $40 \%$ dibandingkan perlakuan kontrol. Hal ini dimungkinkan adanya peranan mikroba yang terkandung dalam pupuk hayati menghasilkan zat-zat pengatur tumbuh berupa asam-asam organik yang mempercepat pertumbuhan tanaman (Kartikawati dkk., 2017) sehingga aliran fotosintat dialokasikan untuk pengisian buah yang menyebabkan bbot buah menjadi bertambah (Onggo dkk., 2015).

Faktor lain yang menyebabkan tidak adanya pengaruh nyata antara satu perlakuan dengan yang lainnya dalam perkembangan buah adalah iklim mikro setempat seperti suhu dan kelembaban (Kusumayati dkk., 2015). Apabila dilihat dari faktor suhu, menunjukkan bahwa ratarata suhu rumah kaca sebesar $31,8^{\circ} \mathrm{C}$ dengan persentase kelembaban sebesar $52 \%$. Sementara jika dilihat dari suhu dan kelembaban optimum untuk tanaman tomat ternyata tidaklah optimum, karena mencapai suhu optimal sebesar $25-30^{\circ} \mathrm{C}$ di siang har dan $16-20^{\circ} \mathrm{C}$ di sore hari sementara kelembaban optimum sebesar 80\% (Rubatzky dan Yamaguchi, 1999). Syakur dkk., (2011) menjelaskan bahwa tingginya suhu dan rendahnya kelembaban menyebabkan laju respirasi dan transpirasi meningkat sehingga tanaman tidak dapat menyerap hara dan nutrisi secara seimbang. Akibatnya proses penyerbukan bunga terhambat dan bunga mudah gugur sehingga laju perombakan karbohidrat untuk pembentukan buah menjadi tidak optimal.

\section{KESIMPULAN}

Nutrisi anorganik yang dikombinasikan dengan pupuk hayati dalam sistem hidroponik tidak mampu meningkatkan populasi Azotobacter sp, kandungan klorofil, serapan $\mathrm{N}$, serta hasil tanaman tomat.

\section{UCAPAN TERIMA KASIH}


Penulis mengucapkan terimakasih kepada Universitas Padjadjaran yang telah mendanai penelitian ini melalui Skema Penelitian Prioritas Unpad 2017. Ucapan terimakasih disampaikan pula kepada Laboratorium Pemuliaan dan Teknologi Benih yang telah memfasilitasi penggunaan alat Chlorophyll Content Meter.

\section{DAFTAR PUSTAKA}

Badan Pusat Statistik dan Direktorat Jenderal Hortikultura. 2014. Produktivitas tomat menurut provinsi, 2010-2014. Badan Pusat Statistik dan Direktorat Jenderal Hortikulura.

Bailey, D. S., and R. S. Ferrarezi. 2017. Valuation of vegetable crops produced in the UVI commercial aquaponic system. Aquaculture Reports. Elsevier,

Cardoso, D. S. C. P., M. A. N. Sediyama, Y. Poltronieri, M. C. M. Fonseca, and Y. F. Neves. 2016. Effect of concentration and $\mathrm{N}: \mathrm{K}$ ratio in nutrient solution for hydroponic production of cucumber. Department of Phytopathology Rev. Caatinga, Mossoró, 30(4): 818 - 824.

Dhanasekar, R., T. Viruthagiri and P. L. Sabarathinam. 2003. Poly (3-hydroxy butyrate) synthesis from a mutant strain Azotobacter vinelandiiutilizing glucose in a batch reactor. Biochemical Engineering Journal. 16: $1-8$.

Hardjowigeno, S. 2010. Ilmu tanah. Akademika Presindo, Jakarta.

Hindersah, R. dan R. Sudirja. 2010. Suhu dan waktu inkubasi untuk optimasi kandungan eksopolisakarida dan fitohormon inokulan cair Azotobacter sp. LKM6. Jurnal Natur Indonesia, 13(1): $67-71$.

Karsono, S., Sudarmodjo, dan Y. Sutiyoso. 2002. Hidroponik: skala rumah tangga. PT AgroMedia Pustaka, Jakarta.

Kartikawati A., O. Trisilawati, dan I. Darwati. 2017. Pemanfaatan pupuk hayati (biofertilizer) pada tanaman rempah dan obat. Jurnal Perspektif, 16 (1): $33-43$.

Kusumayati, N., E. E. Nurlaelih, dan L. Setyobudi. Tingkat keberhasilan pembentukan buah tiga varietas tanaman tomat (Lycopersicon esculentum Mill.) pada lingkungan yang berbeda. Jurnal Produksi Tanaman, 3(8): $683-688$

Larimi, S. B., M. Shakiba, A.D. Mohammadinasab and M. M. Vahed. 2014. Changes in nitrogen and chlorophyll density and leaf area of sweet basil (Ocimum basilicum L.) affected by biofertilizer and nitrogen application. International Journal of Biosciences, 5(9): 256 - 265.

Maboko, M. M., and C. P. Du. Plooy, and D. 2014. Yield of two hydroponically grown tomato cultivars as affected by transplanting stage or direct Seeding. Horticultura Science, 49(4): 438 440.

Marliah A., M. Hayati, dan I. Muliansyah. 2012. Pemanfaatan pupuk organik cair dan hasil beberapa varietas tomat (Lycopersicum esculentum L.). Jurnal Agrista, 16 (3): 122 - 128.

Miller E.C., C.W. Hadley, S.J. Schwartz, J.W. Erdman, T.M.W. Boileau, and S.K Clinton. 2002. Lycopene, tomato products, and prostate cancer prevention, have we established causality? Pure Appl. Chem., 74(8): 1435 - 1441.

Mohapatra, B., D. K. Verma, A. Sen, B. B. Panda, and B. Asthir. 2013. Biofertilizers a gateway to agateway to 
sustainable agriculture. Department of Biotechnology. Indian Institute of Technology. Kharagpur (WestBengal), India.

Novelina, N. Nazir, and M. R. Adrian. 2016. The improvement lycopene availability and antioxidant activities (Bab 1), Agriculture and Agricultural Science Procedia, 9: 328 - 334.

Novizan, 2003. Petunjuk pemupukan yang efektif. Jakarta: Agro Media Pustaka.

Okere, U. V and Semple, K. T. 2012. Biodegradation of PAHs in 'pristine' soils from different climatic regions. Journal Bioremediation and Biodegradation, S1(006): $1-11$.

Onggo, T.M., Sumadi, dan R. Fauziah. 2015. Pertumbuhan, hasil, dan kualitas tomat CV. Marta-9 pada berbagai sistem budidaya dalam rumah plastik di dataran medium jatinangor. Jurnal Kultivasi, 14(1): $298-304$.

Rubatzky, V. E., dan Yamaguchi, M. 1999. Sayuran Dunia. Edisi ke-2. Institut Teknologi Bandung. Bandung. 320 hal.

Rueda, D., G. Valencia, N. Soria, B. B. Rueda. B. Manjunatha, R. R. Kundapur, and M. Selvanayagam. 2016. Effect of Azospirillum spp. and Azotobacter spp. on the growth and a yield of strawberry (Fragaria vesca) in hydroponic system under difeerent nitrogen levels. Journal of Applied Pharmaceutical Science, 6(1): 48 54.

Salik M.R., F. Muhammad F., M.A. Pervez. 2000. Relationship between age of seddlings on productivity of tomato (Lycopersicon esculentum L.) grown under plastic tunnel. Pak. J. Biol. Sci., 3(8): $1260-1261$.
Sampson, P.H., T.P. Zarco, G.H. Mohammed, J.R. Miller, and T. Noland. 2003. Hyperspectral remote sensing of forest condition: estimating chlorophyll content in tolerant hardwoods. Forest Science, 49 (3): $381-391$.

Shelton, D. R. and Parkin, T. B. 1991. Effect of moisture on sorption and biodegradation of carbofuran in soil. J. Agric Food Chem., 39: 2063 2068.

Syakur, Abd., Y. Koesmaryono, H. Suhardiyanto dan M. Ghulamahdi. 2011. Analisis iklim mikro di dalam rumah tanaman untuk memprediksi waktu pembungaan dan matang fisiologis tanaman tomat dengan menggunakan metode artificial Neural Network. Jurnal Dinamika Pertanian, 18(2): $94-10$.

Setiawati, M. R., R. Hindersah, P. Suryatmana, dan B.N. Fitriatin. 2016. Pengembangan pertanian hidroponik terkendali berbasis mikroba potensial. Fakultas Pertanian Universitas Padjadjaran. Sumedang.

United States Department of Agriculture. 2009. Tomatoes (red, ripe, raw, year round average) - nutrient values and weights for edible portion (NDB No: 11529). USDA National Nutrient Database for Standard Reference, Release 22.

Walker, T. S., H.P. Bais, E. Grotewold and J.M. Vivanco. 2003. Root exudation and rhizosphere biology. Plant Physiology, 132: 44-51.

Wijayanti E. dan A.D. Susila. 2013. Pertumbuhan dan produksi dua varietas tomat (Lycopersicon esculentum Mill.) secara hidroponik dengan beberapa komposisi media tanam. Buletin Agrohorti, 1 (1): 102 114. 